\title{
Correction: Knowledge of safe motherhood among women in rural communities in northern Nigeria: implications for maternal mortality reduction
}

Ekechi Okereke $^{1 *}$, Susan Aradeon ${ }^{2}$, Adekunle Akerele ${ }^{1}$, Mustapha Tanko ${ }^{1}$, Ibrahim Yisa ${ }^{1}$ and Benson Obonyo ${ }^{1}$

\section{Correction}

Following the publication of this work [1], some typographical errors were observed which were not detected during the proofreading process prior to publication. To ensure the complete integrity of the study reported in this publication, corrections in Table two (Table 1 here) are being reflected in this publication of a correction to the article. Sincere apologies are expressed for any inconveniences this error in particular may have caused.

Table 1 Socio-demographic distribution of female respondents

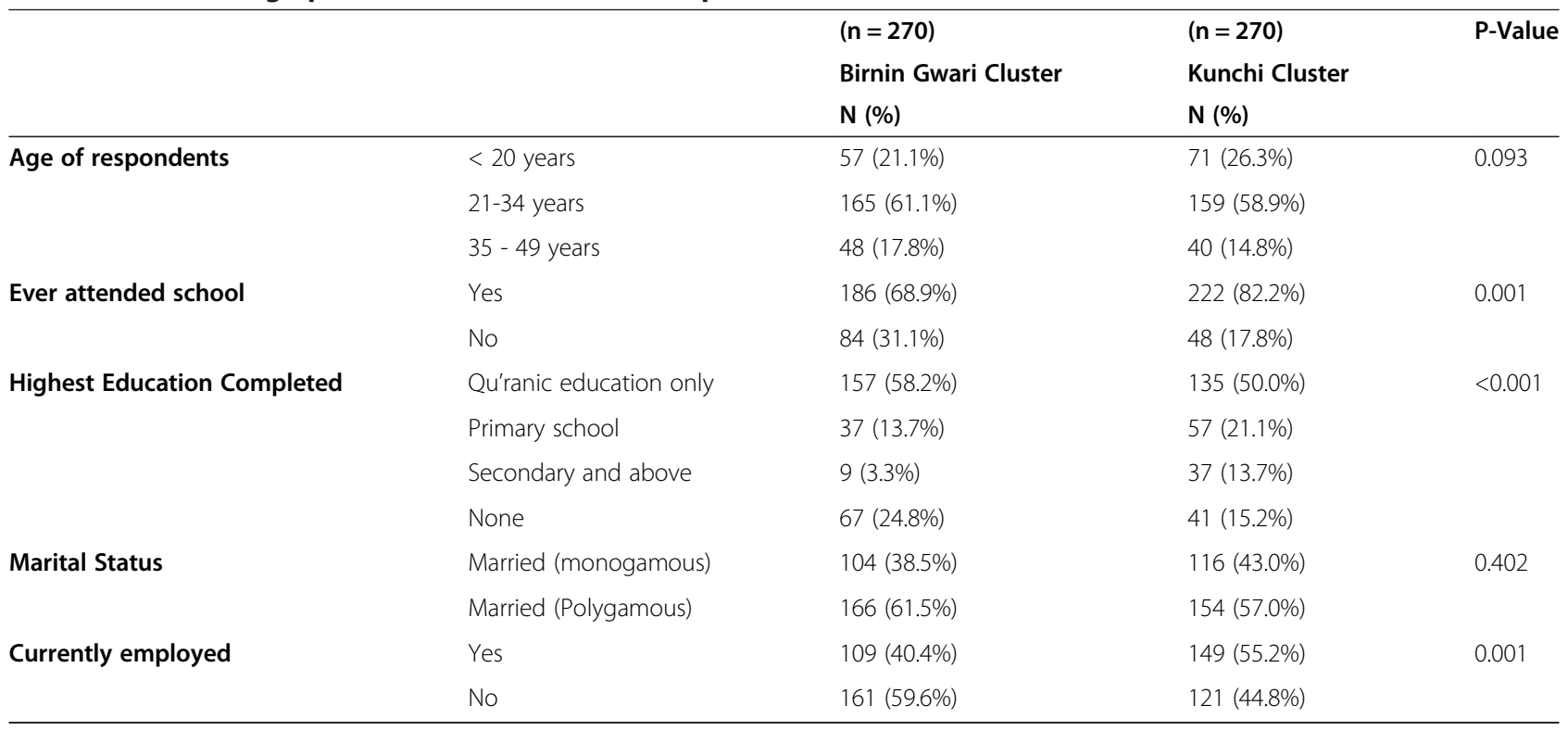

\footnotetext{
* Correspondence: eokereke78@gmail.com

${ }^{1}$ Abt Associates Nigeria, Partnership for Transforming Health Systems Phase

2. (PATHS2), Abuja, Nigeria

Full list of author information is available at the end of the article
} 
Author details

${ }^{1}$ Abt Associates Nigeria, Partnership for Transforming Health Systems Phase 2, (PATHS2), Abuja, Nigeria. ${ }^{2}$ Mannion Daniels, Partnership for Transforming Health Systems Phase 2, (PATHS2), Abuja, Nigeria.

Received: 21 November 2013 Accepted: 21 November 2013

Published: 13 December 2013

\section{Reference}

1. Okereke E, Aradeon S, Akerele A, Tanko M, Yisa I, Obonyo B: Knowledge of safe motherhood among women in rural communities in northern Nigeria: implications for maternal mortality reduction. Reprod Health 2013, 10:57.

doi:10.1186/1742-4755-10-62

Cite this article as: Okereke et al: Correction: Knowledge of safe motherhood among women in rural communities in northern Nigeria: implications for maternal mortality reduction. Reproductive Health 2013 10:62.

Submit your next manuscript to BioMed Central and take full advantage of:

- Convenient online submission

- Thorough peer review

- No space constraints or color figure charges

- Immediate publication on acceptance

- Inclusion in PubMed, CAS, Scopus and Google Scholar

- Research which is freely available for redistribution 